\title{
PEDAGOGICAL CONDITIONS OF PROFESSIONAL TRAINING OF SKILLED MACHINE-BUILDING INDUSTRY WORKERS BY THE DUAL FORM OF EDUCATION
}

\author{
Oleksandr Strilets ${ }^{1}$ \\ 1 graduate student of the Institute of Vocational Education of the National Academy of Educational Sciences of \\ Ukraine Director of Dniprovsky Center for Vocational Education, Ukraine, \\ https://orcid.org/0000-0002-9940-0762, e-mail: svetlana_san@ua.fm
}

\begin{abstract}
.
The relevance of the study is determined by the need to bring the level of professional training of skilled machinebuilding industry workers in line with the requirements of the modern labor market.

Purpose: substantiation of pedagogical conditions of professional training of skilled machine-building industry workers by the dual form of education.

Methods: theoretical analysis of scientific sources - to determine the level of the problem research; comparison in order to study the scientific approaches to solving the problem; systematization - to substantiate its structural components.

Results: pedagogical conditions of professional training of future skilled machine-building industry workers by the dual form of education are considered to be a set of circumstances related to the organization of the educational process in the institution of vocational education and training (VET) and the external educational environment in which cognitive, educational and production activities of applicants for education occur and which are aimed at the formation of the professional knowledge, skills and abilities and the development of professional competence; the following pedagogical conditions are determined (formation of positive motivation for practice-oriented professional training; updating the content of professional and practical training, taking into account the requirements of partner companies; use of active methods and innovative educational technologies; conducting seminars and trainings for production mentors).

Conclusions: the proposed pedagogical conditions of professional training of skilled machine-building industry workers by the dual form of education contribute to the formation of professional competence of skilled machine-building industry workers; the introduction of elements of the dual form of education in the training of future skilled workers is of strategic importance for the development of the country.
\end{abstract}

Keywords: condition, pedagogical condition, dual form of education, professional education, competence.

Introduction. The relevance of the study is determined by the need to bring the level of professional training of skilled machine-building industry workers in line with the requirements of the modern labor market. The best way to solve this problem is to introduce a dual form of education. Substantiation of pedagogical conditions of professional training of skilled machine-building industry workers by the dual form of education involves providing such requirements for the educational process that would promote better learning of educational material, take into account the most important didactic principles, help to harmoniously develop students' hard and soft skills demanded by the machine-building industry.

Sources: The paper took into account the ideas on the theoretical justification of organizational and pedagogical conditions for the formation of professional competence of students in institutions of vocational education and training (hereinafter VET) (A. Aleksiuk (2001), Yu. Babanskiy (2005), 
V. Semychenko (2010), V. Slastenin (2002), features of professional training of future skilled workers in various industries (E. Zeer (2000), I. Zimnyaya (2004), P. Sikorskyi (1998), D. Zakatnov (2012)), L. Petrenko (2013), O. Pometun (2004), J. Raven (2012), competence approach in vocational education and finding ways to form the professional competence of future professionals (G. Dehtiarova (2012), R. Hurevich (2009), M. Artiushyna (2000), N. Bibik (2004), A. Verbytskyi (2004), S. Lisova (2011), V. Luhovyi (2014), N. Nychkalo (2013), O. Ovcharuk (2004), V. Radkevich (2012 a; 2012 b).

The article aims to substantiate the pedagogical conditions of professional training of skilled machine-building industry workers by the dual form of education.

Methods - theoretical analysis of scientific sources - to determine the level of the problem research; comparison - in order to study the scientific approaches to solving the problem; systematization - to substantiate its structural components.

Results and discussion. Pedagogical conditions of professional training of future skilled machinebuilding industry workers by the dual form of education are considered to be a set of circumstances related to the organization of the educational process in the institution of vocational education and training (VET) and the external educational environment in which cognitive, educational and production activities of applicants for education occur and which are aimed at the formation of the professional knowledge, skills and abilities and the development of professional competence.

The first pedagogical condition is the formation of positive motivation for practice-oriented professional training. Practice-oriented professional education is characterized by: fulfillment of a specific goal, which is based on the preparation of the student in accordance with the requirements of a specific customer-employer; synergy of VET institutions and direct customers-employers; priority of professional and practical training.

The success of the implementation of practiceoriented professional education largely depends on the professional motivation of students as a means of forming their professional competence.

The educational process with the use of high-tech equipment, the novelty of the subjects of the professional cycle, applied professional programs, etc., help to increase the motivation of students. If the working educational program is focused on the competencies demanded by employers (the formation of which will take place during theoretical training by solving educational and professional tasks modeled with the inclusion of technological processes of enterprises) and production of the products necessary for the enterprise in a real production situation on all kinds of practice, then not only the quality of training will increase, but also the motivation of students to further employment in the acquired profession will increase.

The motivation of students is also influenced by the implementation of joint interdisciplinary practical work and a comprehensive qualification task in the workplace using the acquired professional knowledge, skills and abilities.

The second pedagogical condition is the updating of the content of educational programs of professional and practical training taking into account technical and technological changes in the machinebuilding industry. The implementation of this condition is carried out through the development and implementation of educational program, didactic, program-methodical and technical means of training in the profession, focused on the development of technical intelligence and the formation of professional competencies, in conditions of a dual form of education.

Activities to develop the curricula for dual education include the following steps:

1. Analysis of the list of required labor functions and their significant labor actions, additional requirements of the employer (based on the report on the results of expert assessment of qualification requirements of the employer) for their grouping into generalized labor functions;

2. Correlation of the state educational standard on the profession and the report on the results of expert assessment of qualification requirements identified by employers to determine training cycles, sections, modules in the structure of the educational plan, the curriculum to include additional educational outcomes.

3. Formation of additional educational results of mastering the educational material on the basis of qualification requirements of employers in the format of dual training.

Qualification requirements of employers must be translated into educational outcomes. The changes, additions and their substantiation made in the program can be described in the explanatory note to the educational plan and specified in the curriculum, carried out by meeting of the corresponding methodical commission.

Conceptually, the implementation of this pedagogical condition is through the active involvement of employers in the development and implementation of the educational program for training skilled 
workers for their own production through motivational, technological and material support of the enterprise.

It is important to follow the algorithm: from determining the results of mastering the educational program to the evaluation procedure and the correct selection of assessment tools, and only then - to the formation of the actual content and structure of the program.

Understanding the goals and the ways to test them makes it possible to build the curriculum in an optimal way. The formation of the structure of the curriculum (composition of professional modules, disciplines) and its content is carried out on the principle of "reverse": first, determine the types of work included in the modules, the content of subjects, then the composition and content of modules / topics, and finally - composition and content of subjects.

The content of the professional module / subject should take into account the synchronization of theory and practice. It is important to take into account that the content of the program is aimed at achieving the goal of education - the development of professional and general professional competencies that determine the qualifications of graduates. Adherence to the algorithm involves the development of an educational program to discuss with a joint creative group the conditions of program implementation, the distribution of responsibilities for the implementation of the program components, which provide a reasonable construction of the educational plan and schedule of the educational process.

Priority in the construction of updated software using elements of the dual form of education is the achievement by graduates of the qualifications required by employers. This is the purpose of cooperation between the parties, to ensure which (taking into account the peculiarities of production), it is determined what pedagogical staff, equipment, infrastructure are needed for conducting the industrial training and practice in production conditions, which schedule of the educational process, educational plan and list of components of its subjects and modules should be.

The third pedagogical condition is the use of active methods and innovative educational technologies. In the formation of professional competence of the future skilled worker, the educational process should be aimed at individualization of educational interaction, integrative learning and the development of technical thinking. In the conditions of dual model of training, there is always a choice of pedagogical technologies, which (in the conditions of reduction of duration of theoretical preparation, increase of hours of professional and practical training in the conditions of production) could provide the creation of a strong basis of future professional activity and which would have innovative character. Innovative transformational approaches to learning involve the formation of a modern model of the graduate who would be ready for the requirements of production due to high professional competence and ability to communicate with other people.

Such technologies can be: design, personality development, case studies, interactive, integrated.

Project-based learning technologies involve the use of active methods of independent work of students, which stimulate their creative thinking, increase the level of mastery of research methods, the ability to work in a group and use different sources of information. The teacher (when using the project technology) determines the timing, scope of tasks, criteria for evaluating the results of work and coordinates the following stages of the project: exploratory, analytical, practical and final.

Personality-development technologies are based on the partnership between the teacher and the student, with high educational, exploratory, research activity of the latter. The peculiarity of this technology is the constant emphasis on the content of education to the requirements of modern enterprise, integrative approaches to modeling lessons, the use of activating teaching aids, including information and communication, as well as modernization of material and technical base.

Case study is a learning technology based on the analysis, solution and discussion of real or simulated professional situations. The strength of this technology is that in solving a certain production situation, the learner integrates knowledge of theory (with acquired skills) in practice, working on the predicted result, through the analysis of a specific production problem, formulating its cause and identifying ways to solve it. When solving production situations, the learner develops skills: analytical (information analysis), practical (application of theoretical knowledge in a practical situation), communicative (ability to work in a group, establish partnerships, present and argue own point of view).

The introduction of integrated learning technology is relevant because the content of vocational education in accordance with the standards of vocational (professional) education in the profession "Turner" has a subject approach. However, the 
professional activity of the future skilled worker is anintegral part of the application of professional competence (subject of activity, equipment, technology, materials science, etc.).

Integrated technology is based on a metasystem combination of similar elements from different subjects through the cyclical interaction of teachers and students. The positives of this system are: the implementation of interdisciplinary links, integration of content, the formation of students' professional competencies based on the consolidation of knowledge gained through differentiated learning, the focus on the development of system thinking. In view of this, interdisciplinary connections, development and students' implementation of complex tasks and projects that require knowledge in various subjects become relevant and practically significant.

Interactive technologies provide a system of joint, controlled, active interaction of all participants in the educational process, which is designed (through individual and group activities) to develop professional competencies and soft skills of students. Built on interactive technologies, training is based on the minimum knowledge of students on the topic, their production experience, cooperation and communication, rapid systematization of knowledge and reflection.

The fourth pedagogical condition is the conducting of seminars and trainings for mentors, which are necessary in the organization of the dual form of education. With the introduction of the system of dual form of education, the main teacher in the workplace should be a mentor, and the institution of mentoring in the system of modern education, unfortunately, is almost lost. Fixed mentors have problems working with students. Mentors, mostly experienced highly qualified workers, perform high-quality technological operations, but have no training in Pedagogy and Psychology, do not always know the requirements of educational programs, the standard of vocational (professional) education when working with students who undergo industrial training and internships in the enterprise conditions. According to the results of the survey, mentors are practically not ready to implement their functions in the training of future skilled workers, including in terms of pedagogical competence.

Conclusions. The pedagogical conditions influencing the formation of the necessary professional competencies of skilled machine-building industry workers include: the formation of positive motivation for practice-oriented vocational training (training of students on high-tech equipment that allows them to perform most of practical, laboratory and diploma work in real production conditions and to form the professional competencies of the turner demanded at work on the high-tech equipment of the enterprises of machine-building industry); updating the content of professional and practical training taking into account the requirements of partner companies (adjusting the list of professional competencies by type of activity due to the active involvement of employers in the development and implementation of an educational program for training skilled workers); use of active methods and innovative educational technologies (individualization of educational interaction, integrative learning, development of technical thinking); conducting seminars and trainings for production mentors (restoration of the mentoring institute).

\section{List of references}

Алексюк, А. М., 2001. Модульне навчання: проблема взаємодії викладачів та студентів. В: Сисоєва, С. О., ред. Педагогічні технологї у неперервній освіті : монографія. Київ : ВІПОЛ. 75-88.

Артюшина, М. В., 2000. Взаємозв'язок сочіально-психологічних та дидактичних умов групової навчальної діяльності студентів: автореф. Кандидат наук. Нац. пед. ун-т ім. М. П. Драгоманова.

Бабанский, Ю. К., 2005. Оптимизация учебно-воспитательного процесса. Методические основы. М.: Педагогика.

Бібік, Н. М., 2004. Компетентнісний підхід: рефлексивний аналіз застосування. В: О. В. Овчарук, ред. Компетентнісний підхід у сучасній освіті: світовий досвід та украӥнські перспективи: бібліотека з освітньої політики. Київ: К.І.С. С. 47-52. ПКПС

Вербицкий, А. А., 2004. Компетентностный подход и теория контекстного обучения. М.: ИЦ

Гуревич, Р. С., 2009 Теорія і практика навчання в професійно-технічних закладах: монографія. Вінниця: ТОВ фірма «Планер», 2009.

Дегтярьова, Г. С., 2012. Принципи педагогічної взаємодії у професійній підготовці. Педагогіка $i$ психологія професійної освіти, 6, с.9-17. 
Закатнов, Д. О., 2012. Особистісно орієнтована освіта як засіб модернізації професійно-технічної підготовки молоді. В: В. А. Савченко (ред.) Напрями реформування системи професійно-технічної освіти в умовах європейської інтеграиії (досвід, аналіз, прогнози): монографія. К: Пед. думка. С. 89-112.

Зеер, Э. Ф., 2000. Ключевые квалификации и компетенции в личностноориентированном профессиональном образовании. Образование и наука, 3. С. 90-102.

Зимняя, И. А., 2004. Ключевые компетенции как результативно-целевая основа компетентностного подхода в образовании. Авторская версия. Москва : Исслед. центр проблем качества подготовки специалистов.

Кулалаєва, Н. В., 2019. Готовність учнів професійно-технічних навчальних закладів до проектної діяльності. В: Науково-методичне забезпечення професійної освіти і навчання: збірник матеріалів XI Всеукраїнської наук.-практ. конф. (звітної), присвяченої 25-річчю НАПН України. К. : ІПТО НАПН України. С. 148-151.

Лісова, С. В., 2011. Компетентнісний підхід у вищій освіті: зарубіжний досвід. В: О. А. Дубасенюк (ред.). Професійна педагогічна освіта: компетентнісний підхід: монографія. Житомир: ЖДУ ім. I. Франка. С. 34-53.

Луговий В. І., 2014. Становлення системи основних понять і категорій компетентнісного підходу в умовах парадигмальних змін в освіті. В: Компетентнісний підхід в освіті: теоретичні засади і практика реалізації : матеріали методол. семінару, 3 квіт. 2014 р., м. Київ. Київ: Ін-т обдарованої дитини НАПН України. Ч. 1, с. 5-18.

Ничкало, Н. Г., 2013. Дидактичні принципи формування комунікативної компетентності майбутніх філологів у позанавчальній діяльності з використанням мультимедійних технологій. Вісник Національної академії державної прикордонної служби України. [online] 4. URL: http://nbuv.gov.ua/jpdf/Vnadps-_2013_4_15.pdf (дата звернення 11 Квітень 2015).

Овчарук, О. В., ред., 2004. Компетентнісний підхід у сучасній освіті: світовий досвід та украӥнські перспективи: бібліотека з освітньої політики. Київ: К.І.С.

Петренко, Л. М., 2013. Теорія і практика розвитку інформаційно-аналітичної компетентності керівників професійно-технічних навчальних закладів: монографія. Дніпропетровськ: IMА-прес.

Пометун, О. І., 2004. Дискусія українських педагогів навколо питань запровадження компетентнісного підходу в українській освіті. О. В. Овчарук, ред. Компетентнісний підхід у сучасній освіті: світовий досвід та українські перспективи. Київ: К.І.С. С. 66-72.

Равен, Дж., 2002. Компетентность в современном обществе: выявление, развитие и реализаџия / пер. с англ. М.: Когито-Центр.

Радкевич, В. О., 2012. Компетентнісний підхід до розроблення державних стандартів професійнотехнічної освіти. Професійно-технічна освіта, 3 (56), с. 8-10.

Радкевич, В. О., 2012. Компетентнісний підхід до професійного навчання персоналу підприємств. Професійна освіта: педагогіка $і$ психологія. Київ, XIV (XIV), с. 277-287.

Сікорський, П. І., 1998. Теоретико-методологічні основи диференційованого навчання : монографія. Львів : Каменяр.

Сластенин, В. А., Исаев, И. Ф., Мищенко, А. И. и Шиянов, Е. Н., 2002. Педагогика: учеб. пособ. для студ. пед. учеб. завед. Москва: Школьная Пресса.

Семиченко, В. А., Снісаренко, О. С., Брюховецька, О. В. та Кудусова, А. Ш., 2010. Плекаємо педагогічну майстерність : навч. посібник. Вінниця : Планер.

\section{Translated \& Transliterated}

Aleksiuk, A. M., 2001. Modulne navchannia: problema vzaiemodii vykladachiv ta studentiv [Modular learning: the problem of interaction between teachers and students.]. V: Sysoieva, S. O., red. Pedahohichni tekhnolohii u neperervnii osviti : monohrafiia [Pedagogical technologies in continuing education: monograph]. Kyiv : VIPOL. 75-88, [in Ukrainian].

Artiushyna, M. V., 2000. Vzaiemozviazok sotsialno-psykholohichnykh ta dydaktychnykh umov hrupovoi navchalnoi diialnosti studentiv: avtoref. Kandydat nauk. [The relationship of socio-psychological and didactic conditions of group learning activities of students: abstract of the Candidate of Sciences]. Nats. ped. un-t im. M. P. Drahomanova [National Pedagogical University named after M.P. Drahomanov], [in Ukrainian]. 
Babanskiy, Yu. K., 2005. Optimizatsiya uchebno-vospitatelnogo protsessa [Optimization of the educational process]. Metodicheskie osnovyi [Methodical bases]. M.: Pedagogika [M.: Pedagogy], [in Russian].

Bibik, N. M., 2004. Kompetentnisnyi pidkhid: refleksyvnyi analiz zastosuvannia [Competence approach: reflexive analysis of application]. V: O. V. Ovcharuk, red. Kompetentnisnyi pidkhid u suchasnii osviti: svitovyi dosvid ta ukrainski perspektyvy: biblioteka z osvitnoi polityky [Competence approach in modern education: world experience and Ukrainian perspectives: library on educational policy]. Kyiv: K.I.S. S. 47-52, [in Ukrainian].

Verbytskyi, A. A., 2004. Kompetentnostnbil podkhod y teoryia kontekstnoho obuchenyia [Competence approach and theory of contextual learning]. M.: YTs PKPS, [in Russian].

Hurevych, R. S., 2009 Teoriia i praktyka navchannia v profesiino-tekhnichnykh zakladakh: monohrafiia [Theory and practice of teaching in vocational schools: monograph]. Vinnytsia: TOV firma «Planer», 2009, [in Ukrainian].

Dehtiarova, H. S., 2012. Pryntsypy pedahohichnoi vzaiemodii u profesiinii pidhotovtsi [Principles of pedagogical interaction in professional training]. Pedahohika i psykholohiia profesiinoi osvity [Pedagogy and psychology of vocational education], 6, s.9-17, [in Ukrainian].

Zakatnov, D. O., 2012. Osobystisno oriientovana osvita yak zasib modernizatsii profesiino-tekhnichnoi pidhotovky molodi [Personally oriented education as a means of modernization of vocational training of youth]. V: V. A. Savchenko (red.) Napriamy reformuvannia systemy profesiino-tekhnichnoi osvity v umovakh yevropeiskoi intehratsii (dosvid, analiz, prohnozy): monohrafiia [Directions of reforming the system of vocational education in terms of European integration (experience, analysis, forecasts): monograph]. K: Ped. dumka. S. 89-112, [in Ukrainian].

Zeer, E. F., 2000. Klyuchevyie kvalifikatsii i kompetentsii v lichnostnoorientirovannom professionalnom obrazovanii [Key qualifications and competencies in personality-oriented vocational education]. Obrazovanie i nauka [Education and Science], 3, s. 90-102, [in Russian].

Zimnyaya, I. A., 2004. Klyuchevyie kompetentsii kak rezultativno-tselevaya osnova kompetentnostnogo podhoda $v$ obrazovanii. Avtorskaya versiya [Key competencies as a result-based basis of the competence approach in education. Author's version]. Moskva : Issled. tsentr problem kachestva podgotovki spetsialistov, [in Russian].

Kulalaieva, N. V., 2019. Hotovnist uchniv profesiino-tekhnichnykh navchalnykh zakladiv do proektnoi diialnosti [Readiness of students of vocational schools for project activities]. V: Naukovo-metodychne zabezpechennia profesiinoi osvity i navchannia: zbirnyk materialiv KhI Vseukrainskoi nauk.-prakt. konf. (zvitnoi), prysviachenoi 25-richchiu NAPN Ukrainy [Scientific and methodological support of vocational education and training: a collection of materials of the XI All-Ukrainian scientific-practical conference (reporting), dedicated to the 25th anniversary of the NAES of Ukraine]. K. : IPTO NAPN Ukrainy. S. 148151, [in Ukrainian].

Lisova, S. V., 2011. Kompetentnisnyi pidkhid u vyshchii osviti: zarubizhnyi dosvid [Competence approach in higher education: foreign experience]. V: O. A. Dubaseniuk (red.). Profesiina pedahohichna osvita: kompetentnisnyi pidkhid: monohrafiia [Professional pedagogical education: competence approach: monograph]. Zhytomyr: ZhDU im. I. Franka. S. 34-53, [in Ukrainian].

Luhovyi, V. I., 2014. Stanovlennia systemy osnovnykh poniat i katehorii kompetentnisnoho pidkhodu v umovakh paradyhmalnykh zmin $\mathrm{v}$ osviti [Formation of the system of basic concepts and categories of the competence approach in the conditions of paradigmatic changes in education]. V: Kompetentnisnyi pidkhid $v$ osviti: teoretychni zasady i praktyka realizatsii : materialy metodol. seminaru, 3 kvit. 2014 r., m. Kyiv [Competence approach in education: theoretical principles and implementation practice: materials of the methodological seminar, April 3. 2014, Kyiv]. Kyiv: In-t obdarovanoi dytyny NAPN Ukrainy [Kyiv: Institute of Gifted Children of the National Academy of Educational Sciences of Ukraine]. Ch. 1, s. 5-18, [in Ukrainian].

Nychkalo, N. H., 2013. Dydaktychni pryntsypy formuvannia komunikatyvnoi kompetentnosti maibutnikh filolohiv u pozanavchalnii diialnosti z vykorystanniam multymediinykh tekhnolohii Didactic principles of formation of communicative competence of future philologists in extracurricular activities with the use of multimedia technologies]. Visnyk Natsionalnoi akademii derzhavnoi prykordonnoi sluzhby Ukrainy [Bulletin of the National Academy of State Border Guard Service of Ukraine]. [online] 4. URL: http://nbuv.gov.ua/jpdf/Vnadps-_2013_4_15.pdf (data zvernennia 11 Kviten 2015), [in Ukrainian]. 
Ovcharuk, O. V., red., 2004. Kompetentnisnyi pidkhid u suchasnii osviti: svitovyi dosvid ta ukrainski perspektyvy: biblioteka z osvitnoi polityky [Competence approach in modern education: world experience and Ukrainian prospects: library on educational policy]. Kyiv: K.I.S, [in Ukrainian].

Petrenko, L. M., 2013. Teoriia i praktyka rozvytku informatsiino-analitychnoi kompetentnosti kerivnykiv profesiino-tekhnichnykh navchalnykh zakladiv: monohrafiia [Theory and practice of development of information-analytical competence of heads of vocational schools: monograph]. Dnipropetrovsk: IMA-pres, [in Ukrainian].

Pometun, O. I., 2004. Dyskusiia ukrainskykh pedahohiv navkolo pytan zaprovadzhennia kompetentnisnoho pidkhodu v ukrainskii osviti [Discussion of Ukrainian teachers around the introduction of a competency-based approach in Ukrainian education]. O. V. Ovcharuk, red. Kompetentnisnyi pidkhid u suchasnii osviti: svitovyi dosvid ta ukrainski perspektyvy [Competence approach in modern education: world experience and Ukrainian perspectives]. Kyiv: K.I.S. S. 66-72, [in Ukrainian].

Raven, Dzh., 2002. Kompetentnost v sovremennom obschestve: vyiyavlenie, razvitie $i$ realizatsiya [Competence in modern society: identification, development and implementation] / per. s angl. M.: KogitoTsentr, [in Russian].

Radkevych, V. O., 2012. Kompetentnisnyi pidkhid do rozroblennia derzhavnykh standartiv profesiinotekhnichnoi osvity [Competence approach to the development of state standards of vocational education. Profesiino-tekhnichna osvita [Vocational education], 3 (56), s. 8-10, [in Ukrainian].

Radkevych, V. O., 2012. Kompetentnisnyi pidkhid do profesiinoho navchannia personalu pidpryiemstv [Competence approach to professional training of enterprise personnel]. Profesiina osvita: pedahohika $i$ psykholohiia [Vocational education: Pedagogy and Psychology]. Kyiv, XIV (XIV), s. 277-287, [in Ukrainian].

Sikorskyi, P. I., 1998. Teoretyko-metodolohichni osnovy dyferentsiiovanoho navchannia: monohrafiia [Theoretical and methodological foundations of differentiated learning: monograph]. Lviv : Kameniar, [in Ukrainian].

Slastenin, V. A., Isaev, I. F., Mischenko, A. I. i Shiyanov, E. N., 2002. Pedagogika: ucheb. posob. dlya stud. ped. ucheb. zaved. [Pedagogy: textbook for students of pedagogical educational institutions]. Moskva: Shkolnaya Pressa, [in Russian].

Semychenko, V. A., Snisarenko, O. S., Briukhovetska, O. V. ta Kudusova, A. Sh., 2010. Plekaiemo pedahohichnu maisternist : navch. Posibnyk [We cherish pedagogical skill: manual]. Vinnytsia : Planer, [in Ukrainian].

\section{ПЕДАГОГІЧНІ УМОВИ ПРОФЕСІЙНОЇ ПІДГОТОВКИ КВАЛІФІ- КОВАНИХ РОБІТНИКІВ МАШИНОБУДІВНОЇ ГАЛУЗІ ЗА ДУАЛЬНОЮ ФОРМОЮ ОСВІТИ}

\section{Олександр Стрілець 1}

1 аспірант Інституту професійно-технічної освіти НАПН України, директор ДПТНЗ «Дніпровський центр професійно-технічної освіти», Україна, https://orcid.org/0000-0002-9940-0762, e-mail: svetlana_san@ua.fm

\section{Реферат.}

Актуальність дослідження визначається необхідністю приведення рівня професійної підготовки кваліфікованих робітників машинобудівної галузі у відповідність до вимог сучасного ринку праці.

Meта: обгрунтування педагогічних умов професійної підготовки кваліфікованих робітників машинобудівної галузі за дуальною формою здобуття освіти. 
Методи: теоретичний аналіз наукових джерел - для з'ясування рівня дослідженості проблеми; порівняння - з метою вивчення наукових підходів до розв'язання проблеми; систематизація - для обгрунтування його структурних компонентів.

Результати: педагогічні умови професійної підготовки майбутніх кваліфікованих робітників машинобудівної галузі за дуальною формою освіти розглядаємо як сукупність обставин, пов'язаних із організацією освітнього процесу в закладі П(ПТ)О і тим зовнішнім освітнім середовищем, у якому відбувається пізнавальна, навчальна й виробнича діяльність здобувачів освіти, спрямована на формування в них професійних знань, умінь і навичок та розвиток професійної компетентності; визначено такі педагогічні умови (формування позитивної мотивації до практико-орієнтованого професійного навчання; оновлення змісту професійно-практичної підготовки з урахуванням вимог підприємств-партнерів; використання активних методів та інноваційних освітніх технологій; проведення семінарів і тренінгів для наставників з виробництва).

Висновки: запропоновані педагогічні умови професійної підготовки кваліфікованих робітників машинобудівної галузі за дуальною формою освіти сприяють формуванню професійної компетентності кваліфікованих робітників машинобудівної галузі; впровадження елементів дуальної форми навчання у професійну підготовку майбутніх кваліфікованих робітників має стратегічне значення для розвитку країни.

Ключові слова: умова, педагогічна умова, дуальна форма освіти, професійна освіта, компетентність.

Received: 08 September 2021

Accept: 04 October 2021 